\title{
Correction to: Operationalizing ecosystem service bundles for strategic sustainability planning: A participatory approach
}

Katja Malmborg (1), Elin Enfors-Kautsky, Cibele Queiroz, Albert Norström, Lisen Schultz

Published online: 15 November 2020

Correction to: Ambio

https://doi.org/10.1007/s13280-020-01378-w

In Fig. 5 in the original publication, cluster 1 was mistakenly labelled as 2, cluster 2 as 3 and cluster 3 as 1 . The updated Fig. 5 is provided in this correction.

The original article can be found online at https://doi.org/10.1007/ s13280-020-01378-w. 
(1)

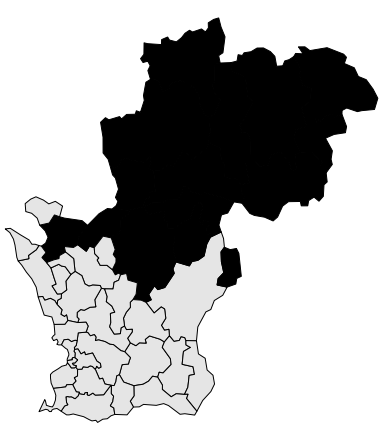

(2)

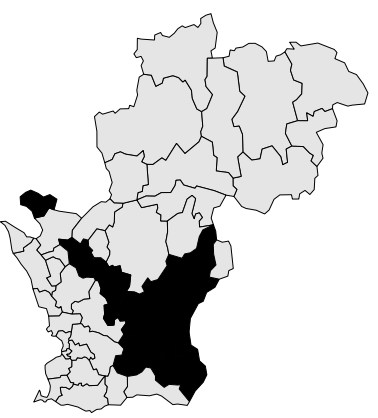

(3)

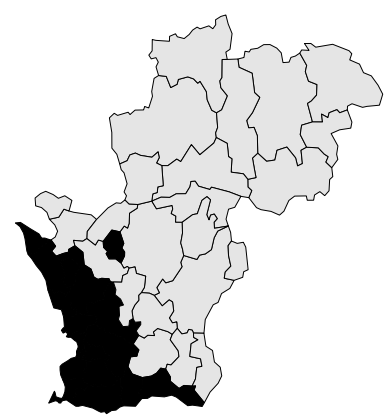

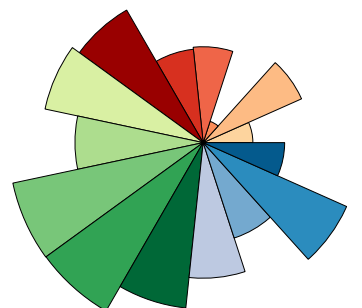
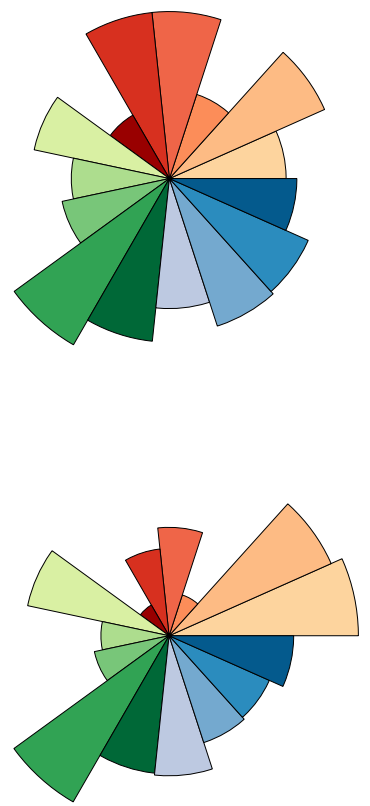
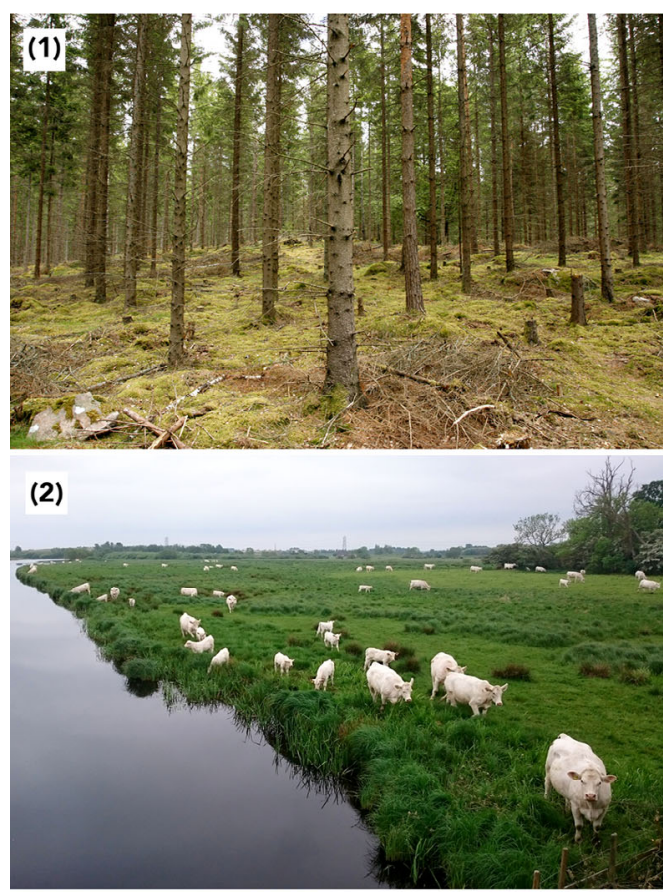

(3)

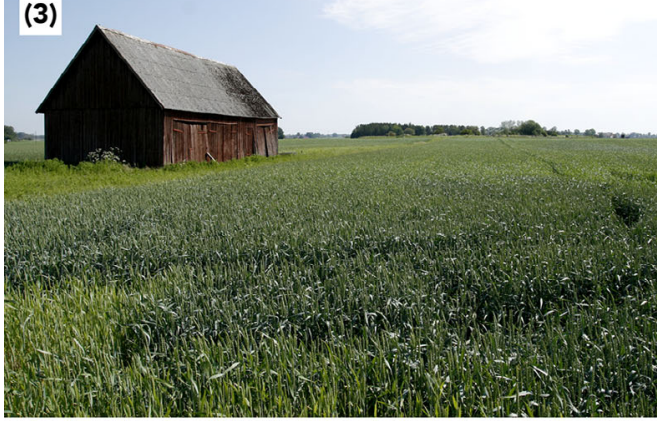

(b)

\section{ECOSYSTEM SERVICES}

Provisioning
Forest production
Milk production
Meat production
Fruit production
Cultivated fodder crops
Cultivated food crops

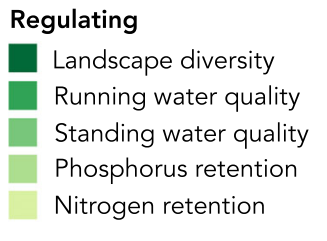
Cultural
Biodiversity heritage
Hunting
Horseback riding
Outdoor recreation

(a)

Fig. 5 a Three clusters of municipalities with their type bundle of ecosystem services. Cluster (1) is forestry-dominated, with high production of regulating services. Cluster (2) has a mixed landscape with high milk and meat production and comparatively high levels of cultural services. Cluster (3) has high production of cultivated food and fodder crops, but generally low levels of all other provisioning and regulating services, and average levels of cultural services. b The photographs show characteristic landscapes from the respective clusters (taken by Katja Malmborg)

Open Access This article is licensed under a Creative Commons Attribution 4.0 International License, which permits use, sharing, adaptation, distribution and reproduction in any medium or format, as long as you give appropriate credit to the original author(s) and the source, provide a link to the Creative Commons licence, and indicate if changes were made. The images or other third party material in this article are included in the article's Creative Commons licence, unless indicated otherwise in a credit line to the material. If material is not included in the article's Creative Commons licence and your intended use is not permitted by statutory regulation or exceeds the permitted use, you will need to obtain permission directly from the copyright holder. To view a copy of this licence, visit http://creativecommons. org/licenses/by/4.0/.

Publisher's Note Springer Nature remains neutral with regard to jurisdictional claims in published maps and institutional affiliations. 
Katja Malmborg $(\bowtie)$

Address: Stockholm Resilience Centre, Stockholm University, Kräftriket 2B, 10691 Stockholm, Sweden.

e-mail: katja.malmborg@su.se

\section{Elin Enfors-Kautsky}

Address: Prosperous Planet, Sveavägen 131, 11346 Stockholm, Sweden.

e-mail: elin.enfors-kautsky@ prosperousplanet.com
Albert Norström

Address: Stockholm Resilience Centre, Stockholm University, Kräftriket 2B, 10691 Stockholm, Sweden.

e-mail: albert.norstrom@su.se

\section{Lisen Schultz}

Address: Stockholm Resilience Centre, Stockholm University, Kräftriket 2B, 10691 Stockholm, Sweden.

e-mail: lisen.schultz@su.s

\section{Cibele Queiroz}

Address: Stockholm Resilience Centre, Stockholm University, Kräf-

triket 2B, 10691 Stockholm, Sweden.

e-mail: cibele.queiroz@su.se 